Robert S., Fox D., Boulay G., Grandclément A., Garrido M., Pasqualini V., Prévost A., Schleyer-Lindenmann A., Trémélo M.-L. (2019) A framework to analyse urban sprawl in the French Mediterranean coastal zone. Regional Environmental Change, 19:559-572 https://doi.org/10.1007/s10113-018-1425-4 
Samuel Robert ${ }^{\mathrm{a}}{ }^{*}$, Dennis Fox ${ }^{\mathrm{a}}$, Guilhem Boulay ${ }^{\mathrm{a}}$, Antoine Grandclément ${ }^{\mathrm{b}}$, Marie Garrido ${ }^{\mathrm{c}, \mathrm{d}}$, Vanina Pasqualini d, e, Aurélie Prévost ${ }^{\mathrm{a}}$, Alexandra Schleyer-Lindenmann ${ }^{\mathrm{a}}$, Marie-Laure Trémélo a

\title{
A framework to analyse urban sprawl in the French Mediterranean coastal zone
}

\author{
Regional Environmental Change (2019) 19:559-572 \\ https://doi.org/10.1007/s10113-018-1425-4
}

\begin{abstract}
${ }^{\text {a }}$ ESPACE, UMR 7300, CNRS, Aix Marseille Universite, Avignon Universite, Universite Nice SophiaAntipolis, F-06204 Nice Cedex, France

${ }^{\mathrm{b}}$ TELEMME, UMR 7303, CNRS, Aix Marseille Universite, F-13094 Aix-en-Provence Cedex 2, France

${ }^{\mathrm{c}}$ Office of Environment of Corsica, Department Strategies and Marine Sciences, F-20600 Bastia, France.

d Sciences pour l'Environnement, UMR 6134, CNRS, Université de Corse, F-20250 Corte, France.

${ }^{\text {e }}$ Stella Mare, UMS 3514, CNRS, Université de Corse, F-20250 Corte, France.
\end{abstract}

* Corresponding author at:

ESPACE, UMR 7300, CNRS, Aix Marseille Universite, Technopole de l'Environnement Arbois Mediterranee, BP 80-13545, Aix-en-Provence Cedex 04, France. Tel. : +33 442908532.

Email : samuel.robert@univ-amu.fr

Email addresses of co-authors :

guilhem.boulay@univ-avignon.fr (G. Boulay)

fox@unice.fr (D. Fox)

garrido@oec.fr (M. Garido)

antoine.grandclement@univ-lr.fr (A. Grandclément)

pasquali@univ-corse.fr (V.Pasqualini)

aurelie.prevost@univ-amu.fr (A. Prevost)

alexandra.lindenmann@univ-amu.fr (A.Schleyer-Lindenmann)

marie-laure.tremelo@univ-amu.fr (M.-L. Trémélo)

\begin{abstract}
As in many other European countries, urbanisation and urban sprawl along the French Mediterranean coast are a major concern. Understanding this phenomenon requires both multi-level and multidisciplinary approaches. In this perspective, this article presents a framework for the observation and analysis of urban sprawl in the French Mediterranean coastal zone. Developed in the context of a scientific coastal observatory with four contrasting study sites, the framework was designed to structure the observation and analysis of urban sprawl dynamics and their driver variables. Although urban expansion is currently slowing in coastal zones, local exceptions can be found and accounted for by historical urban planning and environmental protection measures, local residential tax policies and contradictory perceptions of coastal zones by residents. Our multi-disciplinary initiative is capable of integrating different temporal and spatial scales and has proven relevant in analysing urban sprawl in coastal areas. It shows the need to study coastal areas at finer scales to identify specific dynamics in their local contexts, since these represent the scale at which administrative decisions are made.
\end{abstract}

\section{Keyword}

Urban sprawl, coastal zone, Mediterranean, analytical framework 


\section{1... Introduction}

Increased pressure to develop sound land use policies, protect biodiversity and anticipate coastal natural risks has made the rapid urbanisation of coastal areas a major environmental issue. Coastal zones came under pressure during the second half of the twentieth century as people migrated for both tourism and residential purposes and as maritime shipping increased in the global economy (Small and Nicholls 2003 ; Nicholls et al. 2007). This trend caused a number of environmental and socio-economic problems, particularly in the Mediterranean basin (Cori 1999 ; Datar 2004 ; Benoit and Comeau 2005 ; Gomez and Picarzo 2006 ; McDonnald et al. 2008 ; Hadley 2009).

The Mediterranean coast of France, one of Europe's most urbanised coastal areas (EEA, 2006), embodies many of the issues underlying urban sprawl. Agricultural areas and unprotected natural areas (off-shore and inland) are threatened by urban expansion (Meinesz et al. 1991; Médail and Diadema 2006; Abrantes et al. 2010; Doxa et al. 2017), resulting in a loss of habitats and biodiversity and a standardised landscape quality. The strong land pressure also makes it very difficult for locals to obtain housing (DATAR 2004) and for businesses to set up close to the coast, except in the tourism and real estate sectors (Daviet and Robert, 2012). In 2006, artificial land cover accounted for 31.6\% of land located within $500 \mathrm{~m}$ of the sea (compared to a mean of $28.2 \%$ for French coastal zones in general) but reached 49.6\% in south-eastern France between Marseille and the Italian border (ONML 2009). Between 2008 and 2012, French coastal municipalities occupying only $4 \%$ of the territory accounted for $11.2 \%$ of new housing areas, and $40.4 \%$ of new housing areas in coastal municipalities were located on the Mediterranean coast (ONML 2014). This trend is likely to continue (Léon 2010) and raises several social, political and scientific issues. For example, how has coastal development been integrated into land use planning since the landmark Brundtland report (1985) and especially Agenda 21 of the 1992 Rio summit (Cicin-Sain and Knecht 1998 ; Vallega 1999), whose principles were transposed to France (Deboudt et al. 2008)? Since a total freeze on coastal development is neither feasible nor acceptable, how can coastal benefits be maximised while protecting the environment? Given the exceptionally high tourism pressure on the Mediterranean basin coast (500 million tourists predicted in 2030 compared to 343 million in 2014, according to $\mathrm{UNTWO}^{1}$ ), can the French coast escape an urbanisation process that spares only a few privileged protected natural habitats? These questions are pushing researchers to identify current dynamics, analyse the underlying processes and orient public policy.

Coastal development has been studied for some time, and rapid urbanisation has attracted considerable attention as a dominant trend that is fundamentally non-sustainable if coastal areas are to be preserved. Studies have quantified the area lost to urbanisation, characterised urban morphologies, and at times modelled future trends according to different scenarios (Weng 2002; Catalan et al. 2008; Petrov et al. 2009; Pons and Rullan 2014 ; Romano and Zullo 2014). In addition, some studies have focused on the factors driving urbanisation, including the impacts of land market and urban planning policies, which can orient coastal development (Razin 1998; Malvàrez Garcia et al. 2003; Crawford 2007; Tang 2008; Abrantes et al. 2016). In recent years, coastal submersion and relocation strategies have begun to appear in the scientific literature (Duvat et al. 2013; Meur-Férec 2014; Poumadère et al. 2015; Rey-Valette et al. 2015). Yet despite the number of studies and fields of research, there is a lack of integrated multidisciplinary studies of urban dynamics and their environmental impacts. In general, studies isolate one aspect of the issue, and obtaining a complete picture is difficult.

Our objective is to present a framework for the observation and analysis of urban sprawl on the French Mediterranean coast. Its design was based on a scientific coastal observatory with four study sites. Both the framework and its results are described below.

\footnotetext{
${ }^{1}$ United Nations World Tourism Organisation press release, 15035, 27 May 2015
} 


\section{2... Framework description}

\subsection{The Human-Environment Observatory for Mediterranean coasts}

The "Observatoire Hommes-Milieux Littoral Méditerranéen" (OHM-LM) ${ }^{2}$ was co-created by the Institute of Ecology and Environment (INEE) and the Institute of Social and Human Sciences (INSHS) of the French National Scientific Research Centre (CNRS) ${ }^{3}$ in 2012 with a mandate to study and compare human-environment interactions in Mediterranean coastal zones. Each year it publishes a call for proposals to finance research projects on a wide range of topics and to encourage interactions among disciplines and with local land managers through seminars and other events (Chenorkian 2014). Since its creation, the OHM-LM has financed 36 studies, 6 of which focused specifically on coastal urbanisation; 2 additional studies on this issue had external funding but were conducted under the OHMLM. The observatory fosters the development of multi-disciplinary research on urban sprawl and urbanisation integrating a range of themes like land use, land ownership, landscapes, urban planning, hydrology. Initially launched as individual projects, the studies tend to converge over time as researchers meet to present results, harmonise their spatial and temporal scales of analysis and share data. This evolution has led to the ongoing development of a scientific framework for the study of urban sprawl in coastal areas.

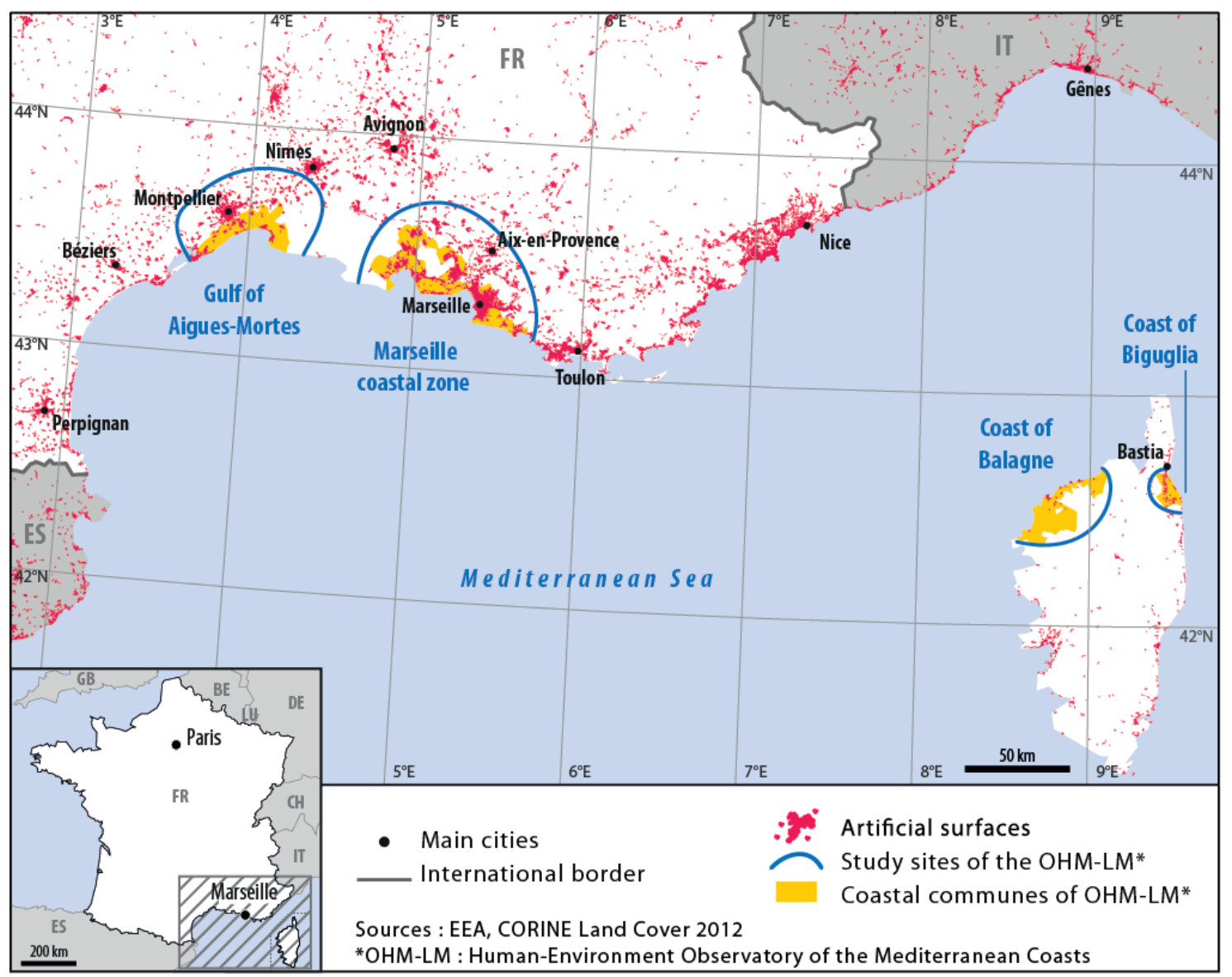

Figure 1. OHM-LM observatory study sites

\subsection{Study sites}

The framework relies on studies conducted in the 4 OHM-LM observatory sites shown in Figure 1. Two of the sites are located on the continent (Marseille coastal zone and Gulf of Aigues-Mortes) while the

\footnotetext{
${ }^{2}$ URL : http://www.ohm-littoral-mediterraneen.fr/

${ }^{3}$ Centre national de la recherche scientifique. URL : http://www.cnrs.fr/
} 
other two are situated on the island of Corsica (Coast of Balagne and Coast of Biguglia). These sites were selected to represent a gradient from low to high urban pressure contexts (Table 1). Balagne is the least urbanised while Marseille is the 3rd largest urban area in France, with major industrial and port infrastructures. However, the two Corsican study sites have recently recorded a strong population increase, unlike the two continental sites. In all, 50 municipalities are included within the observatory perimeter and represent a wide range of environmental and socio-economic conditions: low-lying lagoon coasts, rugged coastlines, coastal risks (erosion, marine submersion), different categories of protected areas, seaside resorts, large and small towns, industrial and yachting harbours, more or less seasonal tourism. This enables a wide range of topics and contexts to be taken into account.

Depending on research objectives, the actual geographical area under study may differ from one project to another. Coastal zone limits for the study sites depend on municipal administrative limits (1986 coastal law), which explains why some municipalities do not extend to the sea but have shores along a lagoon. To address the actual geographical area in question, some studies focus on smaller areas while others extend further inland.

Table 1. Main characteristics of the four study sites

\begin{tabular}{|c|c|c|c|c|}
\hline Study area & Coast of Balagne & Coast of Biguglia & Gulf of Aigues-Mortes & Marseille coastal area \\
\hline $\begin{array}{c}\text { Number of } \\
\text { municipalities }\end{array}$ & 12 & 4 & 14 & 20 \\
\hline Area $\left(\mathbf{k m}^{2}\right)$ & 482 & 123 & 438 & 965 \\
\hline Population 2012 & 17,563 & 25,971 & 121,939 & $1,196,852$ \\
\hline $\begin{array}{c}\text { Population } \\
\text { density } \\
\text { 2012(people / sq } \\
\text { km }\end{array}$ & 36 & 211 & 278 & 1,241 \\
\hline $\begin{array}{c}\text { Mean annual } \\
\text { population } \\
\text { growth rate } \\
1999-2012(\%) \\
\end{array}$ & 1.53 & 2.99 & 1.45 & 0.49 \\
\hline $\begin{array}{l}\text { Artificial area } \\
\text { (CLC 2012) \% }\end{array}$ & 2.9 & 17.0 & 13.3 & 35.8 \\
\hline $\begin{array}{c}\text { Main } \\
\text { characteristics } \\
\text { of the coastal } \\
\text { zone }\end{array}$ & $\begin{array}{l}\text { Rocky shores. Small } \\
\text { old cities on the } \\
\text { seashore. Recent } \\
\text { coastal resorts. } \\
\text { Villages on the } \\
\text { hilltops. First tourist } \\
\text { destination in } \\
\text { Corsica }\end{array}$ & $\begin{array}{l}\text { Protected coastal } \\
\text { lagoon. Inland urban } \\
\text { development close to } \\
\text { Bastia (major } \\
\text { economic pole in } \\
\text { northern Corsica) }\end{array}$ & $\begin{array}{l}\text { Vast complex of several } \\
\text { lagoons. Strong coastal } \\
\text { erosion of the barrier } \\
\text { beach. Small cities, large } \\
\text { coastal resorts and } \\
\text { yachting harbours on the } \\
\text { barrier beach. Close to } \\
\text { Montpellier (popn. about } \\
500,000)\end{array}$ & $\begin{array}{l}\text { Large coastal plain (west), } \\
\text { lagoon (north), rocky } \\
\text { shores and hilly } \\
\text { topography (south and } \\
\text { east). Largest industrial } \\
\text { harbour in France. Third } \\
\text { largest city of France. } \\
\text { Calanques national park } \\
\text { and other protected areas } \\
\text { on the coast nearby }\end{array}$ \\
\hline
\end{tabular}

Data : INSEE 2015 ; EEA 2014

\subsection{Research themes}

Four main research themes form the core of the OHM-LM framework (Figure 2). 


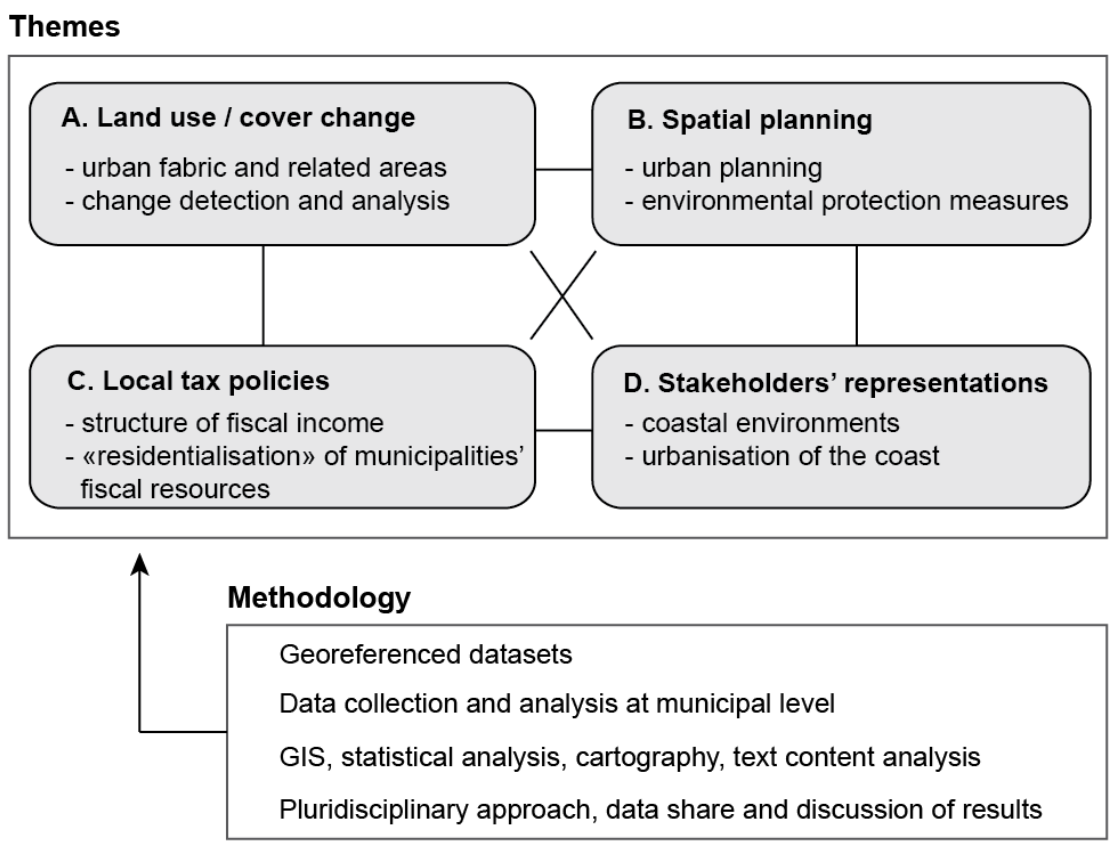

Figure 2. Urban sprawl assessment framework at a local level

\subsubsection{Land use / cover change (A)}

The study of land use / cover change (LUCC) examines how urban areas have evolved over space and time. Based on aerial photographs and geographical databases, large-scale land use maps are created in a Geographical Information System (GIS) environment as we already explained in (Robert et al. 201) and (Robert 2016). In addition to describing changes in land cover and urban morphology, particular attention is paid to land cover transition dynamics between categories. Both urban sprawl and renewal are quantified and discrepancies in rates between major urban areas are analysed. National ("Institut Géographique National" - IGN) and local databases are merged with data acquired from digitising high resolution aerial photographs to create thematic maps and characterise urban structures and changes at different spatial and temporal scales.

\subsubsection{Spatial planning $(B)$}

Coastal LUCC dynamics and urban sprawl can only be understood in the light of historical land planning documents and how elected representatives have exploited these tools or not since the 1967 land planning law, a milestone in the French spatial planning system. For each municipality, a database that includes all past zoning documents and environmental regulations was created, as presented in (Prévost and Robert 2016). The database has two major entries: 1- environmental protection measures with the areas concerned and corresponding urban constraints, and 2- all zoning documents approved at municipal and supra-municipal levels since 1967. These data are then run through statistical and multicriteria analyses to define territorial urban planning anticipation and land use management typologies. These can then be used to generate maps at municipal level in order to identify local trends and anomalies.

\subsubsection{Local tax policies $(C)$}

In addition to urban planning strategies, fiscal policies also play an important role in orienting urban sprawl and LUCC as we demonstrated in (Grandclément and Boulay 2016). The research objective is to investigate how tax income from new residents can be a driver or obstacle to urban sprawl. Generating income from local taxes in a context of diminishing state funding transfers can be perceived as attractive and even essential for some municipalities. Data from the public finance department ("Direction générale des finances publiques" - DGFIP) were used to calculate the proportion of municipal funding 
from residential taxes ${ }^{4}$, and this was then used to characterise municipal resources. Identifying municipalities with a strong income dependence on residential taxes is a first step in investigating how this impacts urbanisation and determining which municipalities maintain or lose potential for future growth. The different scenarios may help predict trends for the near future. The study area goes beyond the limits of the OHM-LM observatory sites by including the entire French continental Mediterranean coast (60 km inland, 1,450 municipalities). Corsica is not included because of unavailability of data. The study covers the Gulf of Aigues-Mortes and coast of Marseille (34 municipalities in all).

\subsubsection{Stakeholders' representations $(D)$}

A wide range of social groups have direct and indirect interests in LUCC dynamics, either because they support urbanisation or because they wish to slow/stop urban sprawl. Such groups include residents, tourists, elected representatives, municipal employees, businesses. The research objective is to identify their perceptions of urbanisation in the coastal zone by bringing to light competing visions of socioeconomic and environmental priorities and relating them to actual LUCC trends. This work was carried out mainly by sociologists, psychologists, and geographers. One study ${ }^{5}$ in particular brought out the inherent ambiguities of perception by different interest groups (Robert et al. 2016). Through an online questionnaire (developed with LimeSurvey), we targeted all residents living in a Mediterranean coastal municipality between the Italian border and the Spanish border. In addition to basic identification questions (age, sex, profession, municipality of residence, number of years in municipality, type of residence), the questionnaire was designed to elicit residents' perception of the coastal landscape. Dominant themes and associations between themes were identified by asking participants to build and give a title to 2 lists of words that they established from a pre-established list of terms evoking different aspects of the landscape (physical, biological, human impacts) and its perception (uses, emotional responses). A quantitative analysis (frequency, similarity, multivariate and automated content analyses using IRAMUTEQ) was run on the data collected to highlight the strongest associations within the lists and to build graphs representing the social representations of the French Mediterranean coastal zone (methodology developed by Degenne and Vergès 1973). Between March and July, 2014, 922 valid responses were recorded.

\section{3... Results}

At this early stage in the OHM-LM history, a full systematic comparison of all themes and sites is not possible, so selected examples are considered below. In some cases, studies were limited to the 2 sites most relevant to research objectives. As expected, sites do not display a single homogeneous dynamic, but reflect site heterogeneities that arise from the local context. However, all sites provide evidence that urban sprawl is the dominant model of local development, contradicting principles of integrated management and balanced development.

\subsection{Land Use / Cover Changes}

In terms of LUCC dynamics, 2 of the 4 study sites (4 Marseille site municipalities located in what is known as the "Côte Bleue" and 4 from the Biguglia coast) show opposing trends in urban sprawl patterns over recent years (Robert et al. 2015). The two sub-zones of the study sites have similar populations (about 25,000) and are located near major urban centres dominating urban change dynamics. However,

\footnotetext{
4 "Residential taxes" mean taxes paid by households to their municipality of residence. They refer to both the housing tax and the property tax on buildings.

${ }^{5}$ VIPLI-Med (Intégrer une connaissance de la représentation et de la visibilité et des représentations du paysage pour la gestion et la planification de l'espace en zone côtière. Analyse spatiale et approche socio-culturelle sur trois littoraux méditerranéens) : project funded by Fondation de France.
} 
urban growth in 2002-2011 in the Biguglia sub-zone was more than 9 times greater than in the "Côte Bleue" Marseille site sub-zone (Table 2). Urban renewal ratios vary substantially both within and between sites. While urban renewal was well established in the municipalities of the "Côte Bleue", it remains weak in Biguglia. The maximum ratio between artificial area annual growth rates is 4.7 in Biguglia (Furiani versus Borgo) and more than 7.5 in the "Côte Bleue" (Le Rove versus Carry-le-Rouet). This demonstrates that although the framework for planning laws is national, local priorities and dynamics dominate trends.

Table 2: Urban LUCC dynamics

\begin{tabular}{|c|c|c|c|c|c|c|}
\hline Site & Commune & $\begin{array}{l}\text { Artificial } \\
\text { areas 2011 } \\
(\%)\end{array}$ & \begin{tabular}{|c|} 
Mean annual \\
evolution $(\%) *$
\end{tabular} & $\begin{array}{c}\text { Urban } \\
\text { sprawl (ha)* }\end{array}$ & $\begin{array}{c}\text { Urban } \\
\text { renewal } \\
\text { (ha)* }\end{array}$ & $\begin{array}{c}\text { Ratio Urban } \\
\text { renewal / } \\
\text { Urban sprawl } \\
*\end{array}$ \\
\hline \multirow[t]{5}{*}{ "Côte Bleue" } & & 16.24 & 0.33 & 33.4 & 52.4 & 1.6 \\
\hline & Carry-le-R. & 30.62 & 0.08 & 1.9 & 11.2 & 5.9 \\
\hline & Ensuès La R. & 12.69 & 0.39 & 10.5 & 22.0 & 2.1 \\
\hline & Le Rove & 10.17 & 0.60 & 13.0 & 9.3 & 0.7 \\
\hline & Sausset-les-P. & 23.61 & 0.33 & 8.0 & 9.9 & 1.2 \\
\hline \multirow[t]{5}{*}{ Biguglia area } & & 19.14 & 3.04 & 587.0 & 136.5 & 0.2 \\
\hline & Biguglia & 23.29 & 2.60 & 132.0 & 26.2 & 0.2 \\
\hline & Borgo & 15.81 & 3.97 & 229.7 & 53.0 & 0.2 \\
\hline & Furiani & 18.14 & 0.85 & 31.8 & 18.3 & 0.6 \\
\hline & Lucciana & 21.50 & 3.78 & 193.5 & 39.0 & 0.2 \\
\hline
\end{tabular}

* Period 2002-2011 for the Biguglia site and 2003-2011 for the Blue Coast site.

In Biguglia, the urban footprint shows greater growth and urban expansion is more dispersed spatially, with new articial surfaces popping up in discrete patterns (Figure 3). This violates the dominant nationallevel governing principle of allowing growth to expand from current urban areas. Several new urbanised sites created in 2002-2011 are isolated from pre-existing urban space, with no apparent spatial strategy for development. In the "Côte Bleue" municipalities, contrastingly, new urban spaces are relatively rare and generally established in continuity with existing urban zones.

Urban renewal in both sites led to increased urban density and new residential developed areas, especially in the "Côte Bleue" zone as we demonstrated in (Robert, 2016). Individual housing outnumbers collective housing, evidence of residents' preferences as favoured by zoning laws. For Biguglia, however, urban renewal also generated new developed areas for economic activities serving the logistics needs of the zone close to Bastia (the main point of entry to Corsica).

\subsection{Spatial planning and environmental protection measures}

One of the explanations for these differences between the two sites (section 3.1) lies in their zoning documents and environmental protection measures. We were able to make a full comparison of the 4 study sites since documentation was collected and analysed for the 50 municipalities concerned. The analysis shows that despite an extensive legal framework empowering municipalities to act on ecological issues, its use by elected representatives varies from site to site, regardless of the biogeographic or ecological pertinence of local conditions. The Gulf of Aigues-Mortes is among the most active in promoting environmental protection, both in terms of the number of decisions and of the ensuing constraints (Figure 4). In Balagne, 6 municipalities are poorly protected while protection in 
Biguglia is intermediate. The coastal zone of Marseille is quite well-protected, but protection is weaker around the Berre lagoon, a large industrial zone, than in the "Côte Bleue" and bay of Marseille areas.

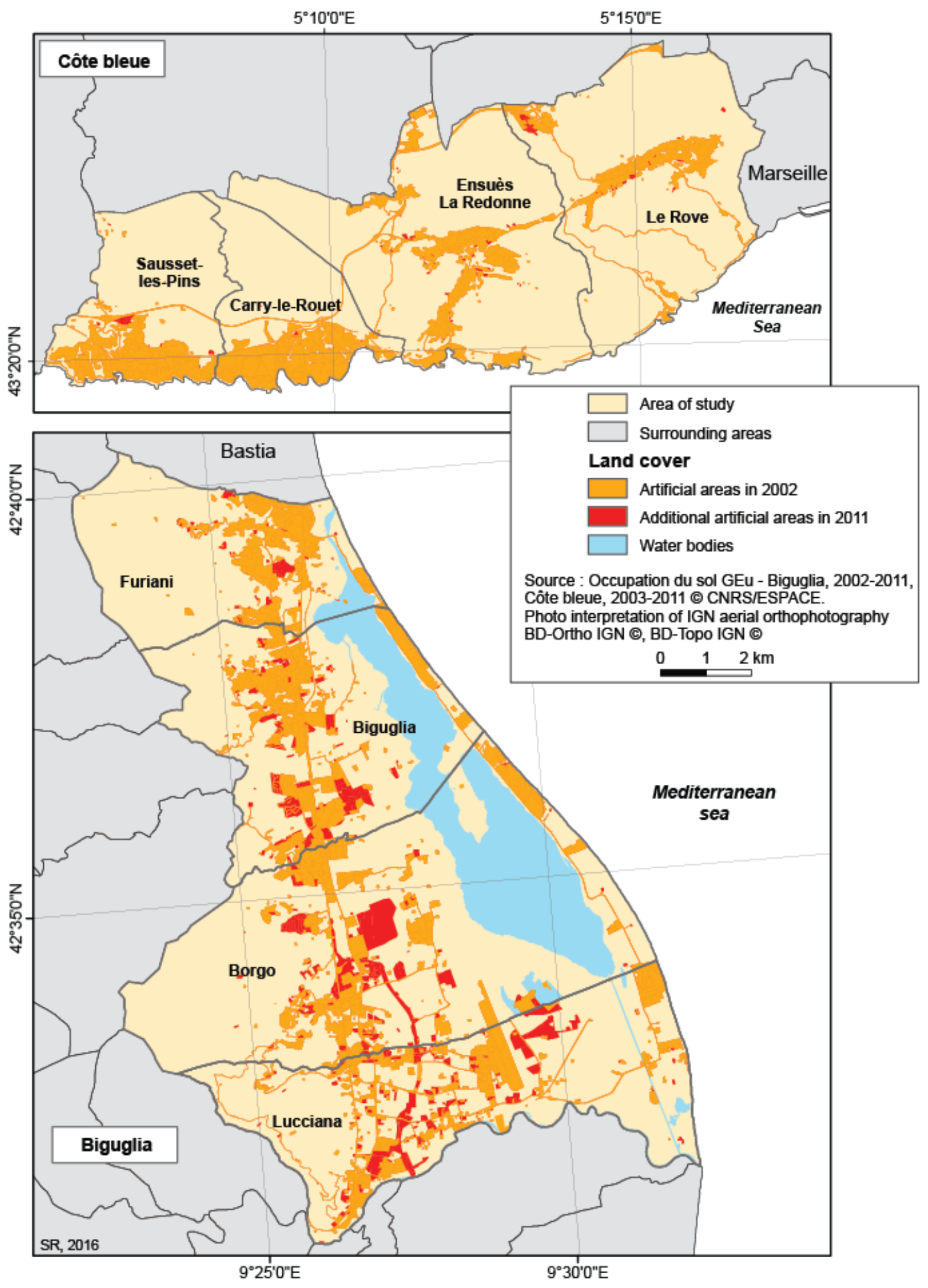

Figure 3. Urban sprawl on the Blue coast and the Biguglia lagoon area 

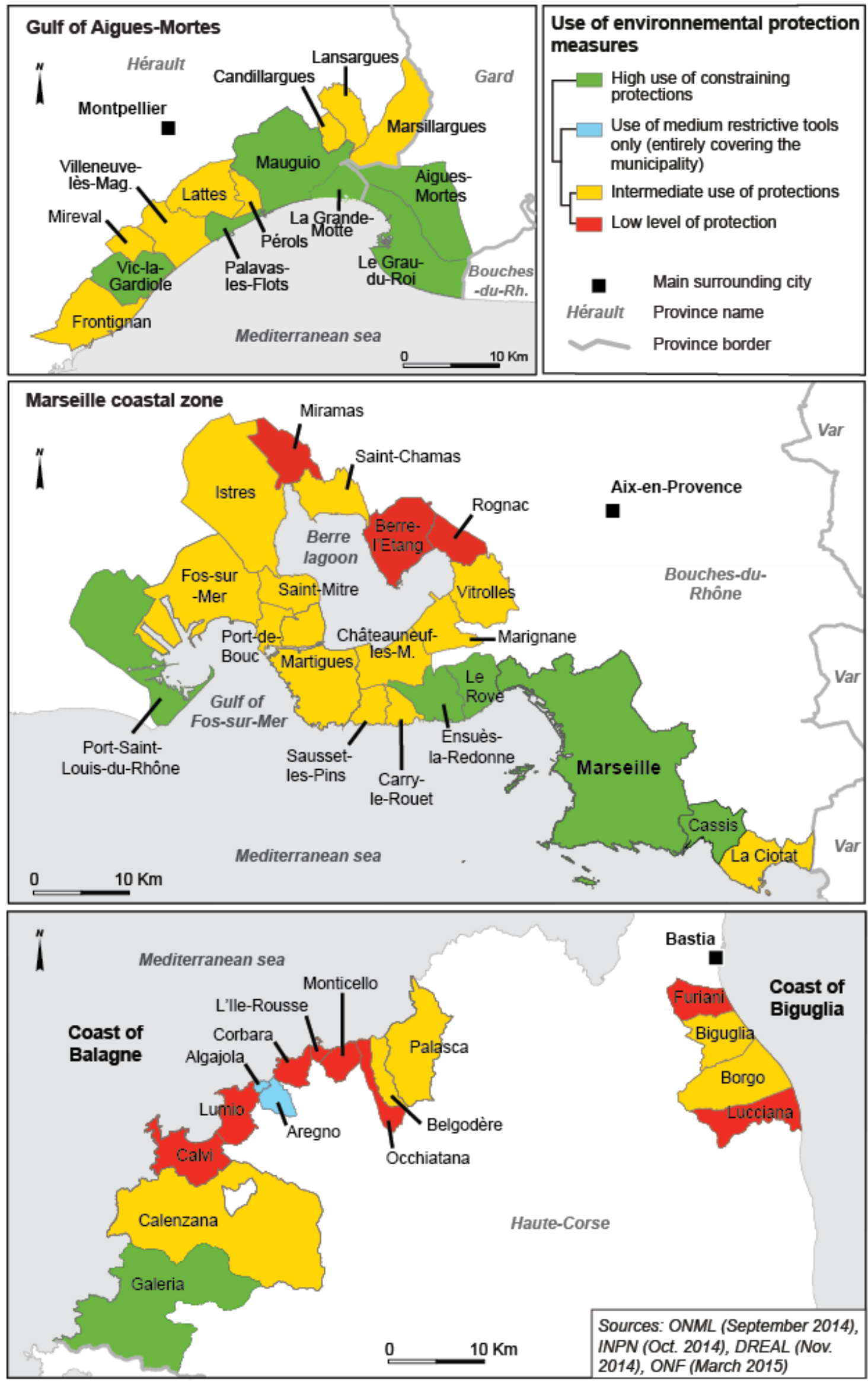

Figure 4. Environmental protection levels 

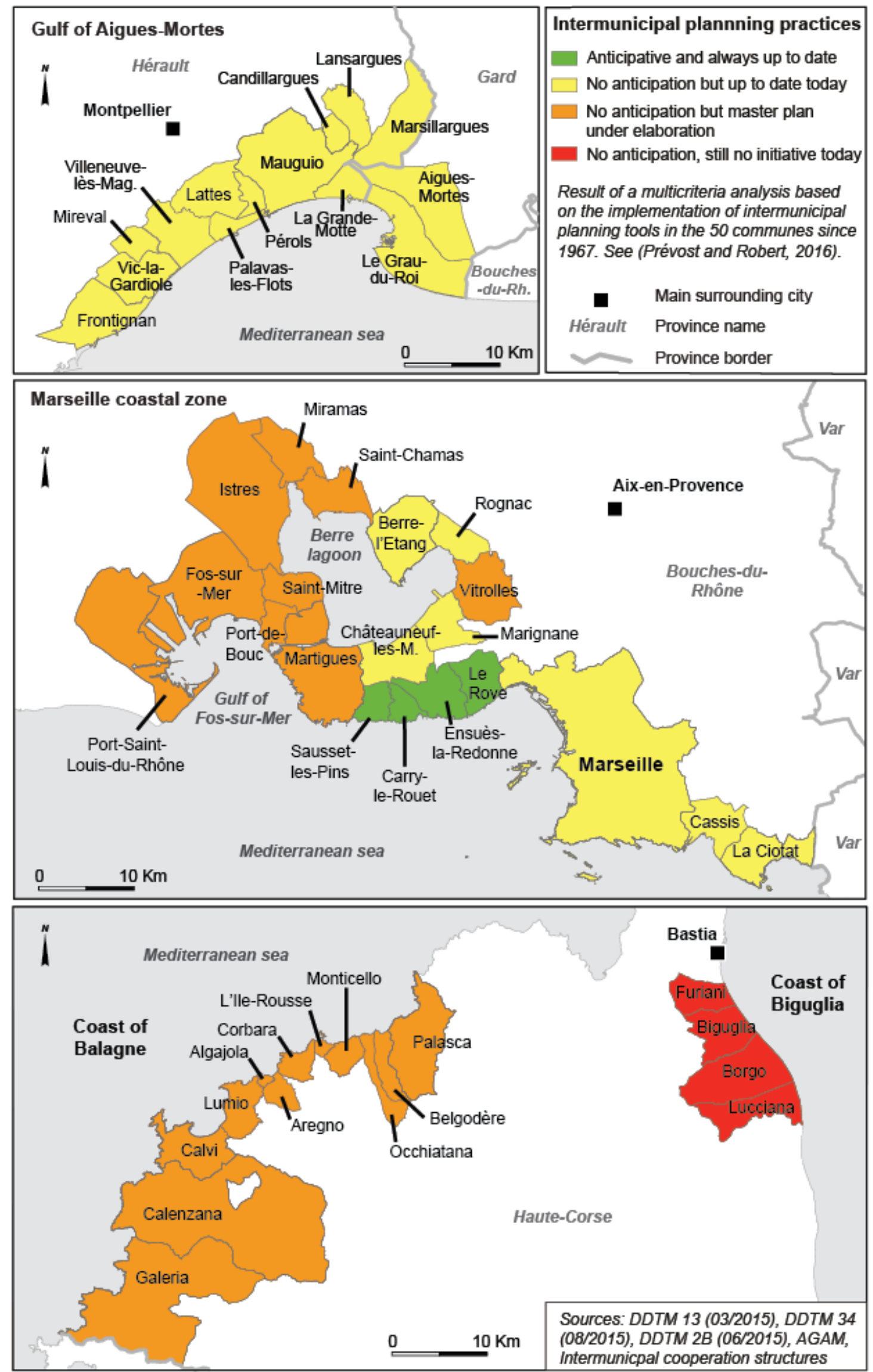

Figure 5. Planning practices at the inter-municipal level 
Urban planning policies reflect the discrepancies in environmental protection described above, which we highlithed in (Prévost and Robert 2016). At the inter-municipal level, analysis shows that municipalities vary widely in their capacity to anticipate urban pressure by implementing planning documents according to national legal frameworks (Figure 5). Only the 4 municipalities of the "Côte Bleue" showed an early and consistent will to anticipate change and control urban sprawl in conformity with the national framework and local priorities, which may explain their limited urban expansion in recent years. Other municipalities hesitated to implement inter-municipal land planning. At best, planning occurred within the "SCOT" framework (French territorial-level planning guidelines), but no other inter-municipal planning documents were produced before 2000 (Gulf of Aigues-Mortes and half the remaining municipalities of the coast of Marseille). While the west of the coast of Marseille and Balagne have their "SCOT" under study but not approved, urban planning is at its worst at the Biguglia site, where inter-municipal planning documents have not even been prepared. This indicates that the management of urban sprawl is worst at the Biguglia site, which is failing to meet national-level priorities and where growth is most sporadic.

\subsection{Local tax policies}

The income tax study monitors changes in the share of municipal incomes derived from residential taxes (which we call "residentialisation") and the fiscal levers pulled by municipalities. Our results highlight that income from residential taxes is greater than the French national average, 63\% versus 58\% respectively (Grandclément and Boulay 2016). Between 2002-2003 and 2009-2010, the share of income derived from residential taxes increased but at a rate slower than the national average, $+3.3 \%$ versus $+4.2 \%$. A finer analysis of the 2 continental observatory sites reveals some interesting details.

Within the Gulf of Aigues-Mortes site, the proportion of residential taxes evolved differently: in half the municipalities it decreased, while in 7 others it increased. Increases tend to be concentrated in the eastern sector of the study site, in municipalities farther from the major urban centers of Montpellier and Nîmes (Figure 6). Maps in Figure 6 also show a decrease in the proportion of municipal income from residential taxes in municipalities bordering the coast. In the coast of Marseille zone, the evolution is more homogeneous. In 12 out of 20 municipalities, there is a moderate increase, while in the industrial zone west of the Berre lagoon, 3 municipalities show strong increases and 3 others slight decreases. High tourism municipalities show a clear negative trend in the proportion of income attributable to residential taxes. In the municipalities of Sausset-les-Pins and Carry-le-Rouet in the "Côte Bleue" zone, evolution is coherent with urban planning, showing that residential tax income is not encouraging municipalities to expand their urbanised areas.

Municipalities can increase residential tax income either by expanding fiscal bases (new residences) or by raising tax rates. Growth of the proportion of residential taxes has slowed in most municipalities (Figure 7), so it appears that they no longer wish to, or cannot, use new urbanisation or higher tax rates to increase their incomes. Only 3 municipalities clearly diverge from this trend: Villeneuve-lèsMaguelonne, Marsillargues and Ensuès-la-Redonne. Here, both fiscal bases - contributing surface area and tax rate - have increased. Others, near the Berre lagoon and the Gulf of Fos-sur-Mer, show more moderate growth patterns. In summary, tax strategies are constrained by urban structure, since coastal municipalities do not have substantial leeway to develop new urban areas due to a lack of available space. 


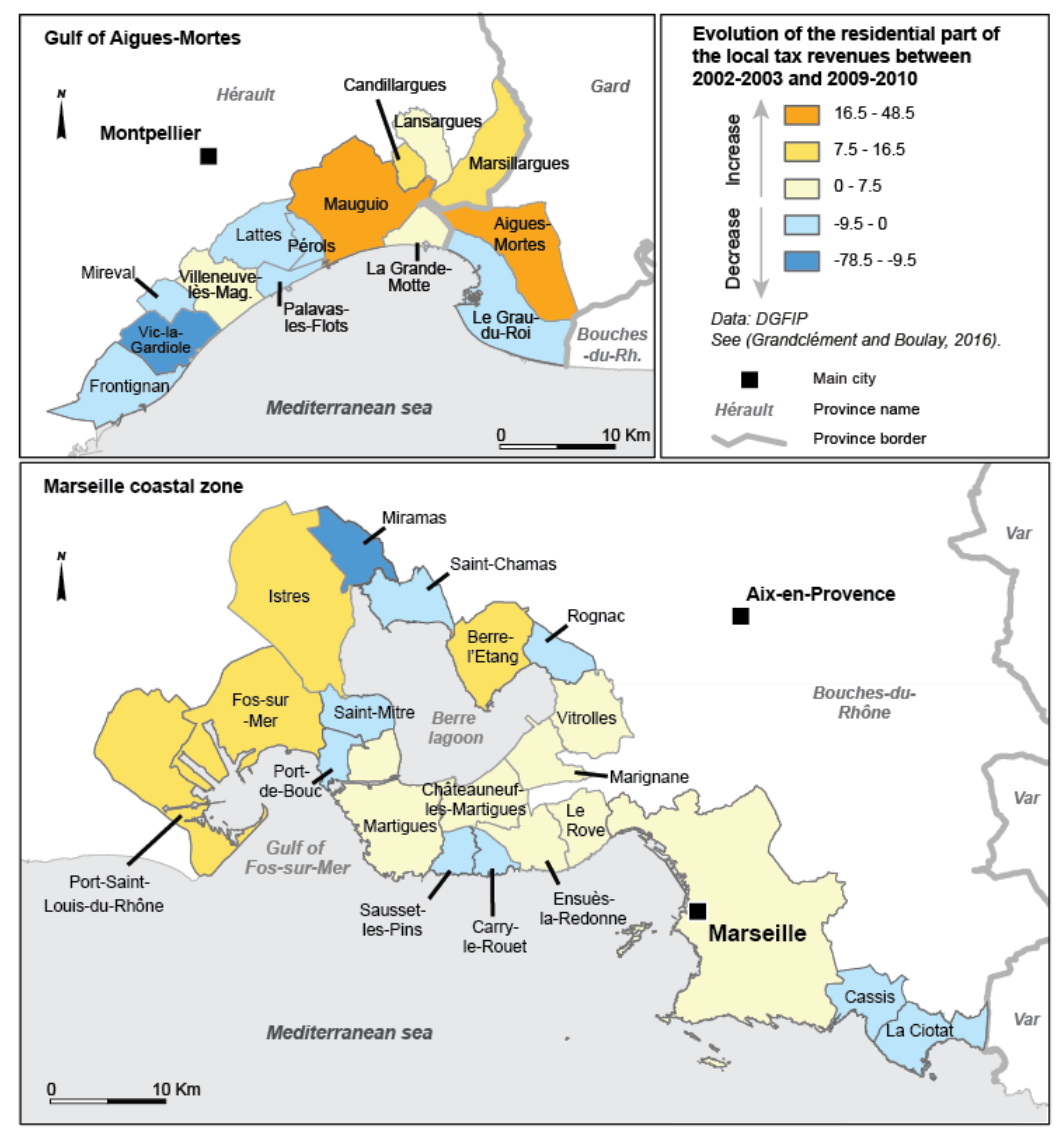

Figure 6. Evolution in the share of residential taxes in municipal incomes

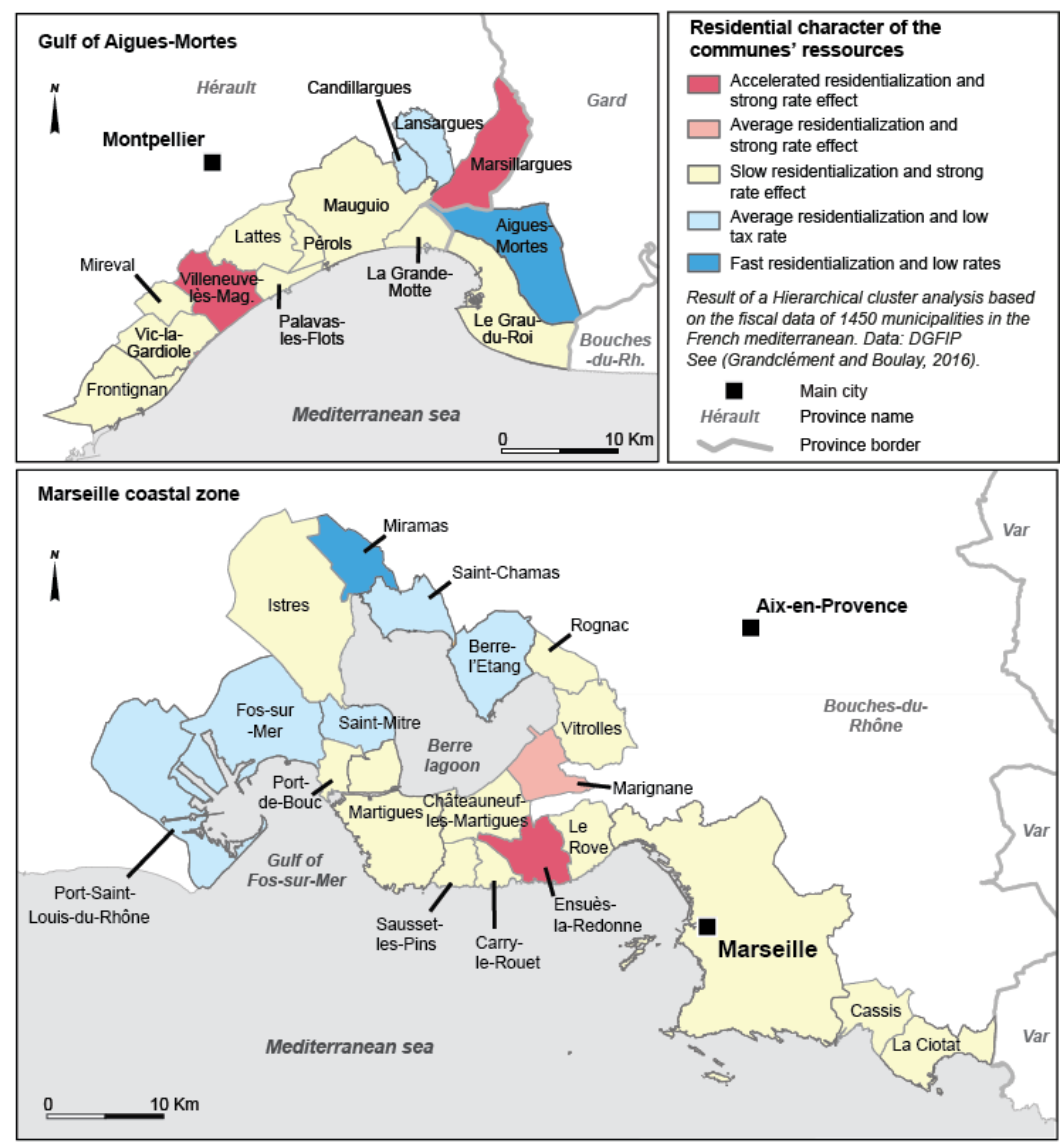

Figure 7. Residentialisation of municipal income 


\subsection{Stakeholders' representations}

Local populations perceive land cover changes in the coastal zone in various ways, and our study brings out some of the ambiguities in this perception (Robert et al. 2016). Associations identified by at least $20 \%$ of the participants revealed two distinct poles in Figure 8. The first corresponds to positive associations with the coastal zone: centred on the term "coastal path" ("sentier côtier"), it reveals associations with the natural landscape, recreational uses and pleasant feelings. This pole is relatively well-structured, with terms related in numerous word triangles, but the strongest association is between "coastal footpath" and scrubland ("garrigue"), indicating that land elements feature more strongly in perceptions than marine elements. The second pole, made up of fewer terms, appears to stand in opposition to the first, associating negative aspects of urbanisation such as "building" and "transformation". This pole is highly structured, therefore strongly representative of the social perception of the coast.

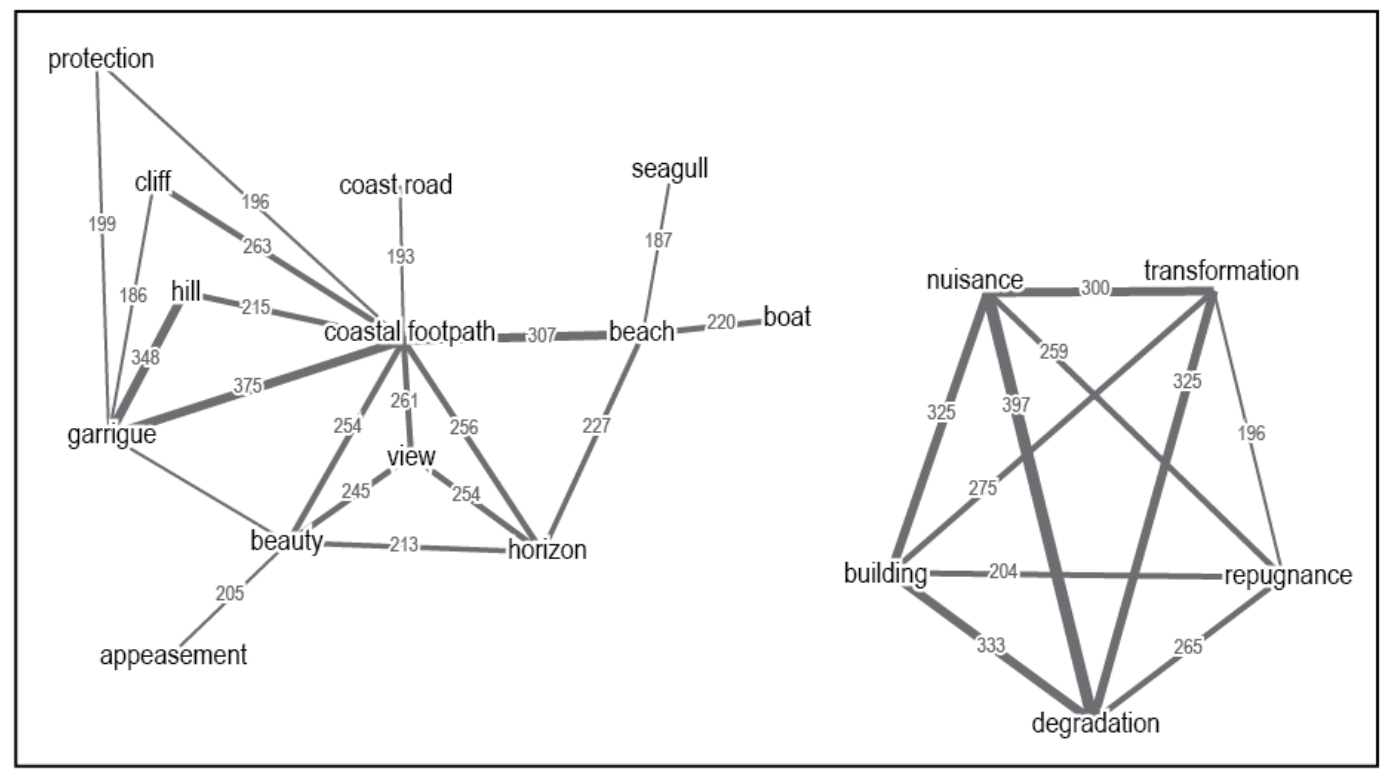

Figure 8. Characteristics of the coastal landscape showing word associations between at least $20 \%$ of respondents

The coastal zone appears to generate contradictory feelings in local residents. On the one hand, they appreciate it as a natural environment and recreational area, but on the other they feel that land cover changes, urbanisation in particular, are deteriorating it. Despite this, the residents idealise the environment and consider themselves fortunate to live and holiday there. This tends to legitimise urbanisation and may explain our observations in the "Côte bleue" and Biguglia sites (section 3.1), where both urban expansion and renewal have mainly produced individual houses in recent years, reinforcing the residential function of these territories.

\section{4... Discussion and perspectives}

\subsection{The framework as a key to understanding urban sprawl in coastal zones}

Although national level data show that coastal development is slowing (ONML 2014), more detailed studies of our sites indicate that some municipalities diverge substantially from this trend. While the coast of Marseille follows national trends, the area around Biguglia, for example, is undergoing rapid urban expansion. These differences are related to how long ago urbanisation began and to a general metropolisation. As elsewhere in France, municipalities located farther from big cities are growing most 
rapidly. However, urban development is not necessarily compromised in regions where urban expansion is limited, because urban renewal and densification allow municipalities to continue to grow socially and economically. Both urban planning (and anticipation) and residential tax income policies are important factors explaining trends in urban development. For example, municipalities pursuing active environmental protection and strong urban planning policies have mastered urban expansion best. Municipalities that have done neither show stong, sometimes negligent, urban expansion. These trends can also be related to municipal fiscal policies. Further studies are needed, but our results suggest several hypotheses. Municipalities where residential tax contributions have increased as a proportion of total municipal income are probably municipalities where urban planning has been limited or largely absent. Municipalities showing opposite trends tend to have a long history of urban planning that is continuously updated. Yet regardless of coastal urban dynamics, the results on social perceptions of coastal zones show contradictory trends. Coastal areas are perceived as natural environments well suited to relaxation and recreational activities, and urban development as a negative encroachment on the landscape. However, development is needed to enable and maintain recreational activities, so it is difficult to have one without the other. Urban expansion in the coastal zone is therefore at the heart of coastal management in general and the conflicting positions of conservation and development. This, in turn, indicates that coastal management must be dealt with at different territorial scales, in particular beyond municipal limits, i.e by reconsidering the perimeter for management of coastal resources.

\subsection{A framework that needs to be consolidated}

While our results are promising, they point to the need to expand the field of study: the explanatory framework remains incomplete. Useful additional factors include geographical (distance to urban centres, service provider locations, available land area for development), socio-political (general principles, local cultural practices, local political priorities) and, of course, a range of economic factors. In addition, past and ongoing studies need to be expanded to include all 4 OHM-LM observatory sites and even, on some issues, covering the entire French Mediterranean coast. This would enable a fuller comparison of results from the different contexts. Urban planning and fiscal strategies could be treated more systematically at the municipal administrative scale. Integrating recent and developing databases would help extend analyses to new directions, fostering a better understanding of the urbanisation process as a whole. Finally, longer time scales need to be considered. Most studies have looked at relatively recent changes (last 50 years for urban planning, 20 years for land cover mapping, and 10 years for fiscal policies). But socio-economic dynamics evolve over longer periods, so many observatory studies should consider longer time scales (at least from the mid $19^{\text {th }}$ century, taking into account both the effect of the industrial revolution and rising coastal tourism), as recently done for the coast of Balagne (Cancellieri and Maupertuis 2016). Modelling needs to be reinforced to include predictive studies of future urban expansion, as was done for the Marseille coast site (Voiron et al. 2014). These changes must be carried out in collaboration with local land managers to enhance our collective understanding of LUCC dynamics and better identify strategic options for the future in a decisionsupport perspective.

\subsection{Widening the scope}

Four new directions have been identified to widen the scope of future research priorities in the OHMLM observatory sites. The first concerns the potential for maintaining agricultural practices within the coastal zone to promote a balance between land uses, landscape types and ecological entities. This research would require the involvement of a wide range of disciplines (especially ecology, agronomy, geography, sociology and economy). The second new research direction concerns environmental risks created by urban expansion along coasts, seeking to improve risk management strategies and land use 
planning. Both coastal submersion and erosion are important, but other risks, such as flooding, storm runoff accumulation, mass movements and forest fires, must also be included depending on local circumstances. In a context of climate change, whether urban dynamics are oriented towards expansion or densification, there are major implications for risk exposure and social vulnerability. Recent tragic events have demonstrated this: catastrophic 2015 flooding on the Côte d'Azur, 2014 and 2015 flooding in Corsica, 2014 flooding in the Hyères Bay area, and devastating fires in the "Côte Bleue" in 2009 and 2016, in Corsica in 2014, and along the Var coast in 2003. The third research priority is oriented towards maintaining ecological continuity within coastal cities and between the coast and inland areas. Urban dynamics in coastal environments influence habitat quality and morphology, environmental priorities and the place of living species in developed environments. An integrated approach linking urban, agricultural and natural coastal environments could be based on priorities defined in the above two research areas. The fourth and final research axis should deal with whether socio-demographic dimensions of urbanisation are consistent with the model of sustainable development. The numerous amenities of coastal zones make them particularly attractive (and therefore expensive), so they are often occupied by wealthier social classes, and access is often more limited for the less wealthy. This corresponds to the concept of ecological inequality, and coastal development should evolve to integrate more equal access to landscapes, beaches and the coast in general.

\section{Conclusion}

Although France remains a country with a strong central government, and even though its territorial management policies are generally considered efficient, coastal development along the Mediterranean shows strong regional contrasts. Despite a tendency towards slower urban expansion in coastal zones, local exceptions can be found and accounted for by historical urban planning and environmental protection measures, local residential tax policies and contradictory perceptions of coastal zones by residents. These factors contribute to the different urban trajectories encountered in the study sites. The multi-disciplinary framework capable of integrating different temporal and spatial scales described here has proven useful for analysing urban sprawl and LUCC dynamics in coastal areas. It also shows the need to study coastal areas at a fine scale in order to identify specific dynamics in their local context, since this is the scale at which administrative decisions are made. Despite repeated calls in recent years to change our relationship with the environment, to adapt to climate change, to reduce our ecological footprint and to develop integrated management strategies, it is clear that coastal management frequently fails to meet these expectations. Local scale studies are therefore necessary to measure how local interests and priorities interact with national scale policies. Scientists must collaborate more closely with local land managers and residents in order to develop a shared understanding of dynamics and to envisage new pathways for future development.

\section{Acknowledgements}

This work received financial support from the Human-Environment Observatory of the Mediterranean Coast (OHM littoral méditerranéen) and from the DRIIHM Labex, CNRS.

\section{Reference list}

Abrantes, P., Soulard, C., Jarrige, F., Laurens, L. (2010) Dynamiques urbaines et mutations des espaces agricoles en Languedoc-Roussillon (France). Cybergeo Eur. J. Geogr. http://dx.doi.org/10.4000/cybergeo.22869 (document 485). 
Abrantes P, Fontes I, Gomez E, Rocha J (2016) Compliance of land cover changes with municipal land use planning: Evidence from the Lisbon metropolitan region (1990-2007). Land Use Policy 51-120134. doi:10.1016/j.landusepol.2015.10.023

Benoit G, Comeau A (eds) (2005) A Sustainable Future for the Mediterranean. The Blue Plan's Environment and Development Outlook. Earthscan, London

Cancelieri J, Maupertuis MA (dir.) (2016) Le jardin de la Corse. La Balagne entre villes et campagnes $\left(\mathrm{XI}^{\mathrm{e}}-\mathrm{XXI}^{\mathrm{e}}\right.$ sicèle). Cnrs Editions, Paris

Catalàn B, Saurí D, Serra P (2008) Urban sprawl in the Mediterranean?: Patterns of growth and change in the Barcelona Metropolitan Region 1993-2000. Landscape and Urban Planning 85: 174-184. doi:10.1016/j.landurbplan.2007.11.004

Chenorkian R (2014) Elements constitutifs des Observatoires hommes-milieux, origine et évolutions. In: Chenorkian R and Robert S (eds.) Les interactions hommes-milieux. Questions et pratiques de la recherche en environnement. Quae, Paris, pp 23-38

Cicin-Sain B, Knecht R (1998) Integrated coastal and ocean management: concepts and practices, Island Press, Washington

Cori B (1999) Spatial dynamics of Mediterranean coastal regions. Journal of Coastal Conservation 5: 105-112. doi: 10.1007/BF02802747

Crawford TW (2007) Where does the coast sprawl the most? Trajectories of residential development and sprawl in coastal North Carolina, 1971-2000. Landscape and Urban Planning 83 : 294-307. doi:10.1016/j.landurbplan.2007.05.004

DATAR (2004) Construire ensemble un développement équilibré du littoral. La Documentation française/DATAR, Paris

Daviet S., Robert S. (2012) Faut-il bannir l'industrie des territoires méditerranéens ? : Analyser la place de l'industrie dans la durabilité des territoires. In : Mésini B. (Ed.). Aménagement durable des territoires méditerranéens. Presses Universitaires de Provence, Aix-en-Provence, pp 93-110.

Deboudt P, Dauvin JC, Lozachmeur O (2008) Recent developments in coastal zone management in France : The transition towards integrated coastal zone management (1973-2007). Ocean \& Coastal Management 51 : 212-228. doi:10.1016/j.ocecoaman.2007.09.005

Degenne A, Vergès P (1973) Introduction à l'analyse de similitude. Revue française de sociologie, 14 : $474-512$

Doxa A., Albert C.A., Leriche A., Saatkamp A. (2017) Prioritizing conservation areas for coastal plant diversity under increasing urbanization. Journal of Environmental Management, 201 : 425-434. doi : 10.1016/j.jenvman.2017.06.021

Duvat V, Magnan A, Pouget F (2013) Exposure of atoll population to coastal erosion and flooding : a South Tarawa assessment, Kiribati. Sustainability Science, Understanding and Managing Global Change in Small Islands, $8: 423-440$. doi : 10.1007/s11625-013-0215-7

EEA, 2006. The changing faces of Europe's coastal areas. European Environment Agency, Copenhagen, EEA Report 6. http://www.eea.europa.eu/publications/eea_report_2006_6

Gómez R, Picarzo L (eds.) (2006) Destrucción a toda costa 2006. Informe sobre la situación del littoral español. Greenpeace España, Madrid 
Grandclément A, Boulay G (2016) Residential function and local fiscal resources on the French Mediterranean coastal areas. L’Espace Geographique 44: 57-72.

Hadley D (2009) Land use and the coastal zone. Land Use Policy 26S: S198-S203, doi : 10.1016/j.landusepol.2009.09.014

Léon O (2010) La Population des régions en 2040. Les écarts de croissance démographique pourraient se resserrer. INSEE Première, 1326. http://www.insee.fr/fr/ffc/ipweb/ip1326/ip1326.pdf Accessed 30 september 2016

Malvárez Garcia G, Pollard J, Domínguez Rodriguez R (2003) The planning and practice of coastal zone management in Southern Spain. Journal of Sustainable Tourism 11: 204-223. doi: $10.1080 / 09669580308667203$

Mcdonald RI, Kareiva P, Forman RTT (2008) The implications of current and future urbanization for global protected areas and biodiversity conservation. Biological conservation, 141: 1695-1703.

Medail F., Diadema K. (2006) Biodiversité végétale méditerranéenne et anthropisation : approches macro et micro-régionales, Annales de géographie, 651: 618-640.

Meinesz, A., Lefevre, J.R., Astier, J.M. (1991) Impact of coastal development on the infralittoral zone along the southeastern Mediterranean shore of continental France. Mar. Pollut. Bull. 343-347. http://dx.doi.org/10.1016/0025-326x(91)90698-r.

Meur-férec C (2014) Plonevez-les-Flots : un territoire fictif pour souligner les dilemmes des élus locaux face à la gestion des risques côtiers. L’Espace Géographique 43 : 18-34.

Nicholls RJ, Wong PP, Burkett VR, Codignotto JO, Hay JE, McLean RF, Ragoonaden S and Woodroffe CD (2007) Coastal systems and low-lying areas. Climate Change 2007: Impacts, Adaptation and Vulnerability. Contribution of Working Group II to the Fourth Assessment Report of the Intergovernmental Panel on Climate Change, M.L. Parry, O.F. Canziani, J.P. Palutikof, P.J. van der Linden and C.E. Hanson, Eds., Cambridge University Press, Cambridge, UK, 315-356

ONML, 2014. Evolution de la construction de logements entre 1990 et 2012 sur le littoral métropolitain. Les fiches thématiques de l'Observatoire National de la Mer et du Littoral, MEDDE-SOeS, 5 p.

ONML, 2009. Occupation du sol en 2006 et artificialisation depuis 2000 en function de la distance à la mer. Les fiches thématiques de l'Observatoire National de la Mer et du Littoral, MEDDE-SOeS, 6 p.

Petrov L, Lavalle C, Kasanko M (2009) Urban land use scenarios for a tourist region in Europe: applying the MOLAND model to Algarve, Portugal. Landscape and Urban Planning 92: 10-23. doi:10.1016/j.landurbplan.2009.01.011

Pons A, Rullan O (2014) The expansion of urbanisation in the Balearic Islands (1956-2006). Journal of Marine and Island Cultures 3: 78-88, doi:10.1016/j.imic.2014.11.004

Poumadère M, Bertoldo R, Idier D, Mallet C, Oliveros C, Robin M (2015) Coastal vulnerabilities under the deliberation of stakeholders: The case of two French sandy beaches. Ocean and Coastal Management 105: 166-176. doi : 10.1016/j.ocecoaman.2014.12.024

Prévost A, Robert S (2016) Local spatial planning practices in four French Mediterranean coastal territories under pressure. Land Use Policy 56: 68-80. DOI: 10.1016/j.landusepol.2016.04.034

Razin E (1998) Policies to Control Urban Sprawl: Planning Regulations or Changes in the 'Rules of the Game'?. Urban Studies, 35 : 321-340. 
Rey-Valette H, Rulleau B, Hellequin AP., Meur-Férec C, Flanquart H (2015) Second-home owners and sea level rise: the case of the Languedoc-Roussillon region (France). Journal of Policy Research in Tourism, Leisure and Events, 7: 32-47. doi: 10.1080/19407963.2014.942734

Robert S (2016) Entre étalement et densification: une approche fine de l'urbanisation littorale sur la Côte bleue, Provence. Cybergeo : European Journal of Geography, document 764. doi: $10.4000 /$ cybergeo. 27451

Robert S, Cicille P, Schleyer-Lindenmann A (2016) Appréhender les modes d'habiter le littoral par les représentations sociales du paysage. In: Robert $\mathrm{S}$ and Melin H (Eds.). Habiter le littoral. Enjeux contemporains. Presses universitaires de Provence, Aix-en-Provence, pp 79-93.

Robert S, Prévost A, Fox D, Trémélo ML, Pasqualini V (2015) Coastal Urbanization and Land Planning in Southern France. In: Özhan E (Ed.). Proceedings of the Twelfth International Conference on the Mediteranean Coastal Environment, MEDCOAST 15, 1-2, 119-130.

Romano B, Zullo F (2014) The urban transformation of Italy's Adriatic coastal strip: Fifty years of unsustainability. Land Use Policy 38: 26-36. doi:10.1016/j.landusepol.2013.10.001

Small C, Nicholls R J (2003) A global analysis of human settlement in coastal zones. Journal of Coastal Research 19: 584-599. URL : http://www.jstor.org/stable/4299200

Tang Z (2008) Evaluating local coastal zone land use planning capacities in California. Ocean and Coastal Management 51: 544-555. doi:10.1016/j.ocecoaman.2008.06.001

Vallega A (1999) Fundamentals of Integrated Coastal Management. Kluwer Academic Publishers, Dordrecht

Voiron C, Decoupigny F, Liziard S, Ornon A, Roussel D, Séry R (2014) PLUMES : Pression Littorale Urbaine : Modélisation, Environnement, Simulation. <halshs-00980986>https://hal.archivesouvertes.fr/halshs-00980986/document

Wen Q (2002) Land use change analysis in teh Zhujiang delta of China using satellite remote sensing, GIS and stochastic modelling. Journal of Environmental Management 64: 273-284. Doi : 10.1006/jema.2001.0509 